\section{Why Constructive Resilience?}

\section{An Autobiographical \\ Essay}

MICHAEL L. PENN

\section{INTRODUCTION}

I was born in a small house that had been built by my uncles on a rocky and barren piece of land that my grandmother acquired by saving the meager wages that she earned cleaning White folks' houses in North Carolina. Since the land was not fertile, we could not grow upon it anything to eat. In addition, because the land was not yet connected to the city, there was no running water, no electricity, and no inside toilet. We went to the bathroom in an outhouse located down the road.

One day, through our good fortune, a school bus crashed in a ditch on my grandmother's property. When the city did not tow the wreckage away, my mother told my uncles to right the bus, remove the seats, and make it our new home. We lived in that bus for a few years until a city official came by and pronounced the bus "unfit for human habitation." He said that we had to move, and that we had to move immediately. Since our family had grown in number, we could not move back into my grandmother's little house. And so, my mother packed our bags, took a few chicken sandwiches that my grandmother had prepared, and loaded the four of us onto a Greyhound bus that took us to New York. In this way, were we part of the mass migration of Negroes from the South.

In the Bedford-Stuyvesant neighborhood of New York, where we lived, there were no Whites. All of my neighbors were either Black or Puerto Rican. We were a close neighborhood. And although there were gangs and occasional murders on the block, we were closer to one another than I have ever been with any people. We were bound together by racism, which kept us out of other neighborhoods, and by our poverty, which made us rely on one another.

When I was in the third grade, for example, two children from my school would show up at our door at about 7:30 every morning during the week. They would ring the bell, we would let them in, and they would go sit in the living room, waiting for us to go to school together. My mother always invited them to breakfast, an offer they never turned down. Years later, one of these boys - by then a young mantold me that the meal that he and his brother had at my house was their only meal. He said that without us, they would have had to go to school and, in his words, "be hungry all day."

At another time, a man stopped by our house while we were sitting on the stoop. He asked my mother if she had some food because he was hungry. At that time my mother had only one can of pork and beans left for her six children, but she felt compassion for the 
man and invited him in to share that meal. When the man left, he said to my mother, "For as long as you live, you will never have to worry about feeding your children again." My mother said that he had been an angel, sent to us "unawares." What was remarkable is that from that day forward, our family always had food. And so, we were close in my neighborhood because we really needed both the Lord and one another. I also suspect that we shared in the way that we did because there were habits that had been developed by the slaves that were still in our repertoire. And although we did not have the words for it at the time, we knew something about constructive resilience.

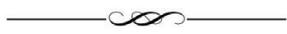

Every summer, my mother would put us all on the bus and send us back to the South to be with my relatives. As a curious, bothersome child, I took the chance to speak with many old Black folks who were very close to the days of slavery. I quite naturally wanted to know how they survived those days. One day, I learned that the slaves used to recite what sounded to me like a poem. It went:

A charge to keep, I have; a God to glorify - who gave His love my soul to save, and fit it for the sky. To serve the present age, my calling to fulfill. O may these all my powers engage to do my Master's will.

They would also sing this in a call-response style in the little Baptist Church that we would attend on Sundays. The song was always led by the oldest members of the community. They were not good singers, but the sound of their voices would move our tender hearts and we would begin to cry.

My grandparents told me that many of the slaves believed that each soul has a destiny, that each soul is held in the hand of God and that each has a role to play. They said that if we lived our lives with as much honor and dignity as possible, given our circumstances, that we would reap the harvest of this life - that we would gather the fruit of human existence. And so, although my relatives were poor and uneducated, they were also philosophers who understood some very important things about life. They had access to some of the profound truths that animate what I understand to be constructive resilience.

When I was in the eighth grade, my teacher, Ms. Maria Paul, told me to appear promptly at her office after school. "Don't be late," she said, adding that I should also bring my friend, Michael Bivens. When we arrived, she asked us if we knew what the word "detrimental" meant. We did not. She taught us the definition, and then gave us about twenty other words to learn that day. Our instructions were to come back the following day to learn another set of words. Again, she emphasized that we should not be late.

For a year, Ms. Paul - the only White person with whom I had been 
closely related as a child - would teach me and my friend words from a book called Eighty Ways to Words of Wisdom. At the end of the year, she asked us if we would like to go to boarding school in New England. We said that while we didn't know anything about boarding school, we would go if she recommended it.

And so, in the fall of 1973, my friend and I headed to boarding school in New England. In this way did Ms. Paul "make a way out of no way" and give us both a future that we could never have had otherwise. Years later, after I had completed my PhD and Michael Bivens had become an executive for the Coca-Cola Company, we went back to New York and found Ms. Paul living in Long Island with her mother. We treated her to dinner because we wanted to thank her for what she had done for us. When we asked her why she had done these things, she said simply that she was "a teacher" and "that is what teachers do." Like my relatives in North Carolina, and like the neighbors on my block, Ms. Paul knew something about constructive resilience. She joined in the practice of it by laboring, quietly behind the scenes, to remedy the deficits that she knew would prevent many economically impoverished children like Michael Bivens and me from realizing more of our potential.

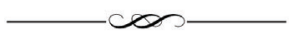

After high school, I joined the U.S. Navy and became a navigations petty officer aboard a ballistic missile submarine. And although our ship's homeport was in the north of Scotland, as we neared the end of my time in the service, we took the submarine to a port in South Carolina for renovations and repairs. One night my crewmates and I went dancing. This occurred in the late seventies or early eighties, and I was one of only a handful of African American submariners at the time.

Unmindful of the problems that might be associated with race, my crewmates had elected to go to a dance hall that played country and western music and taught line dancing. And although I felt quite out of place, after they had been dancing for a while, I sheepishly joined them. Just when I had relaxed a bit and had begun to enjoy myself, a small group of White men surrounded me and asked what a "n ... like me" was doing in that place. They said that I should "get the f... out," and their words, coming as they did after I had begun to imagine that I had been accepted, dismantled my naïve optimism and rendered me dazed and disoriented. With my heart pounding and my mind in disarray, I made it to the street and returned to the ship.

That experience really hurt me. I had been living in what one early scholar in the field of racial identity development called the "pre-encounter" phase of racial identity consciousness. ${ }^{1}$ I had been thinking that we are all the same, and that all of the differences between us

1 See, William E. Cross Jr. "The Negro to Black Conversion Experience: Towards a Psychology of Black Liberation.” 
are superficial. In this phase, the Black American is not yet fully aware of how powerful, violent, and grotesque racism can be. Once its ugly face flashes before you, in much the way that monsters might appear in dreams, the heart is made angry or afraid. If it is to recover its capacity to love in the land of "race relations," one will have to have practice in constructive resilience.

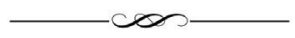

When I was an undergraduate in college, I had dreams that I was soon to meet my wife. These dreams occurred regularly for many months. In my dreams, I could never see her face because she was ever shrouded in light, but I knew that she was a woman of purity and goodness.

When I finally encountered Kathy while standing at the sink at a friend's house, I turned to her and said, "We should go out sometime." She replied, "Yes, we should go out today." Everyone present was as surprised as I was at how our deeply intimate encounter appeared to unfold without premeditation. And although I did not want to have to face the trial of an interracial relationship, on the very first day that I met her, I had the sense that we would be married.

When I learned that she had two children who were six and seven years old, I proposed that we should all go to the Science Museum; and so we did. On the way home, I remembered my dreams and told Kathy that I thought that we were going to marry. She replied, "Maybe." That same night, after speaking together on the phone for many hours, we were engaged.

After we were married, I learned that Kathy's family had not had much experience interacting with Black people. In fact, her grandfather, Charles, told her that I could not enter his house. Since my wife and her two children had been having breakfast at their grandparents' home every Sunday for many years, I did not want my presence in the family to disrupt their bond. This meant that each Sunday morning I would have to drop them at Charles' and return to pick them up a few hours later. Kathy, who was very spiritual, very pure and noble minded, would say to me, with the most tender of hearts, that I should not worry, that he would change.

Sure enough, four years after we were married, Charles called me on the phone. He said that he was very sorry about the way that he had treated me, that I was a wonderful person and that he hoped that I would forgive him. He wanted to send me a wedding present. A few days later, a table and four chairs arrived at our house. From that day onward, I would have breakfast with him and the rest of the family at his home. Just before he died, I was living in Switzerland on sabbatical. He wanted to know, "Where is Michael?" My wife said, "Michael is in Switzerland." He wanted me to know that he loved me.

My wife - like my relatives in North Carolina, my neighbors in Brooklyn, and my teacher Ms. Paul-knew something about constructive resilience. What I perceive in Kathy is the intuition that the manifestation of good 
qualities in circumstances that are harsh and inimical to them can move and transform the human heart. Indeed, it was not easy for either of us to manifest kindness and respect as her grandfather acted in racist ways. His change of heart, coming as it did in the late evening of his life, was - to each of us - a kind of miracle. In this way did the whole episode reveal more about the nature and power of constructive resilience.

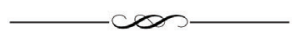

When I was a professor living in Switzerland, I met the mathematician and philosopher Professor William S. Hatcher, whom I called "Hatcher" and everyone else called "Bill."

Hatcher was a White American, and he became my mentor and closest friend. Everyone who knew him, or who read his work, whether in philosophy, religion, or mathematics, knew that Hatcher had a brilliant mind. He was so brilliant that, sometimes, when I listened to him speak, the molecules in my body would begin to vibrate and I would start to sweat from the sheer excitement generated by his ideas. And as much as he was brilliant, Hatcher was also kindhearted, thoughtful, and generous. He was a philosopher who lived out his profound Bahá'í beliefs.

In one of his seminal works, Love, Power, and Justice: The Dynamics of Authentic Morality, Hatcher noted that the great moral challenge facing every human person is to enter into proper relationship with other living beings. This challenge is especially difficult, he noted, when we seek to enter into morally authentic relationships with those who either wittingly or unwittingly oppress, degrade, and dehumanize us. To be in proper relationship, he noted, is to relate to others in such a manner as to maximize the possibility that they will be able to "come forth," that because of their association with us, even our oppressors might have the chance to become more of what they are capable of becoming. And although the words for it did not exist at that time, as I think of it now, it seems that the approach to social change that Hatcher advocated was in harmony with the notion of constructive resilience.

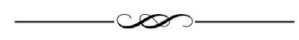

The murder of Mr. George Floyd by a Minneapolis police officer on Memorial Day in 2020 made it difficult to think of constructive resilience. The coroner's report said that Mr. Floyd's death took eight or nine minutes. During several of those minutes he said that he could not breathe. When he could no longer speak for himself, some African Americans who were watching nearby pleaded with the officer on his behalf. The officer was unmoved. He continued to calmly press his knee into Mr. Floyd's neck until he was dead. When the ambulance arrived, Mr. Floyd's lifeless body was rolled onto a gurney and taken away. No one attempted CPR.

Mr. Floyd's death sent many of us, both Black and White, into mourning and deep sorrow. Others were enraged. In the wake of these experiences, we 
wondered, again, whether the soul of America could be saved; and if it could be saved, we wondered, again, about how this might be accomplished.

Hatcher would always say, both in his talks and in his written works, that if the nation is to be saved it will require the coming into being of a "new race" of men and women who can work closely together, over long periods of time, in order to nurture the practice of love and justice. Because Hatcher had been born a Southern White man, and yet embodied so much genuine love and respect for people of color, it seemed to me that what he had been suggesting was in the realm of possibility.

A few weeks before he died, Hatcher said that I should visit him in Canada. I replied that I could not go to Canada because my passport was at the embassy awaiting a visa that would allow me to travel to China. He insisted that I should go to the airport, buy a ticket, and fly to Canada - and so I did. At the airport I was advised that without a passport, border security was likely to send me back to the States. I said that I would take my chances.

When I arrived at the passport check in Toronto, I told them that I did not have my passport but that I had been "summoned" to Canada by my mentor, Professor William S. Hatcher. The officer asked me for Hatcher's phone number and called him. Hatcher confirmed that he had, indeed, summoned me to Canada; and so they welcomed me in.

After three days, on the eve of my departure, Hatcher came into my room and sat on the floor beside my bed. It was very powerful to have such a monumental figure sitting on the floor in that way. He asked me, three times in succession, whether I was "willing to sacrifice." Each time, I replied that I was, indeed, willing to sacrifice. Then he declared "you cannot achieve anything great in this life unless you are willing to sacrifice." When he had completed his brief discourse, he rose, went to the door, and said that he loved me. I responded, "I love you too." On my way to China some time later, my phone quivered and I read the message that Professor Hatcher had died. I realize now that the sacrifices of which he spoke were those that are necessary in order to serve the needs of the world. He wanted me to exercise constructive resilience.

While I am not sure that I fully understand the nature of it, I have, in my life, seen many beautiful examples of constructive resilience. The Universal House of Justice writes of its features in its letter to the Bahá'í students of Iran who were forced to suffer "disappointing and shameful" "official acts" that deprived them of access to higher education. In addressing these young friends in a letter dated 9 September 2007, the House of Justice counseled them to strive to "transcend" the opposition that they face with "constructive resilience." They were further encouraged to peer "beyond the distress" of their difficulties, and endeavor to "translate the Teachings of the new Faith into actions of spiritual and social 
development." Reading such things, I sometimes think that constructive resilience may be a way of being and acting in the world that pursues social change by seeking to harvest, through the force of wise, persistent, and spiritually informed action, whatever prospects for development may be hidden in our exposure to oppression.

In contemplating its nature, one is reminded of the way that Jacob wrestled with God:

That night Jacob got up and took his two wives, his two female servants and his eleven sons and crossed the stream, he sent over all his possessions. So Jacob was left alone, and a man wrestled with him until daybreak. When the man saw that he could not overpower him, he touched the socket of Jacob's hip so that his hip was wrenched as he wrestled with the man. Then the man said, "Let me go, for it is daybreak." But Jacob replied, "I will not let you go unless you bless me." The man asked him, "What is your name?" "Jacob" he answered. Then the man said, "Your name will no longer be Jacob, but Israel, because you have struggled with God and with humans and have overcome." (Genesis 32:22-28)

Jacob demonstrates constructive resilience when he refuses to end this encounter without reaping a harvest. He insists on gathering some fruit. Indeed, as the myth of Sisyphus suggests, the most absurd thing is to suffer for nothing - to suffer and have no chance of deriving any benefit. Those who practice constructive resilience, like Jacob and the Bahá'í students of Iran, are seeking to take from their suffering some kind of blessing, some manner of benefit. And while this cannot always be realized, constructive resilience appears to be grounded in the conviction that many forms of suffering contain a hidden gift, an unrealized potential, "a blessing in disguise."

In graduate school, my training was in clinical and experimental psychopathology. This is a field that has taught us much about suffering. Experimental psychopathologists try to create in the laboratory, often using animals, conditions that mimic the development of psychological disease or disability in human beings. It is a field that is most interested in understanding the conditions that lead to reactive disorders-like anxiety, hopelessness, or depression - which tend to develop as a consequence of exposure to certain kinds of stress.

A wide range of studies has shown that the experiences that generate the most terrible outcomes are stressful experiences about which subjects are powerless to do anything. These experiences tend to produce both negative mental health outcomes and problems with behavioral health that are typically manifested in high levels of aggression and violence directed against the self and others. 
What is most interesting about this experimental work is that it has revealed that it is not always the painful experience itself that generates these bad outcomes, but rather the perception that the suffering is essentially meaningless and that the organism is powerless to do anything that would be effective to escape, avoid, or benefit from it in any way.

The typical learned helplessness experiment employs the "triadic design" in which one group of subjects receives controllable painful experiences, a second group, yoked to the first, receives uncontrollable painful experiences of equal intensity and duration as the first group, and a third group is exposed to neither controllable nor uncontrollable events. In Hiroto's classic human helplessness study, for instance, college students were exposed to either loud controllable noises or loud uncontrollable noises. A third group was not exposed to any noises. Subjects were then tested on a simple task in which noise termination was controllable by all subjects. Hiroto's findings are typical in that groups receiving controllable noises and no noises quickly learned to terminate the undesirable noises, whereas subjects previously exposed to uncontrollable noises failed to terminate aversive noises during the procedure.

According to the learned helplessness hypothesis, learning that events are uncontrollable results in motivational, cognitive, and emotional deficits. The motivational deficit is characterized by a kind of paralysis of will and is believed to arise from the expectation that responding is futile. The cognitive deficit is manifested by a difficulty in learning that responses do have an influence on outcomes when, in actuality, they do. And the depressed emotion characteristic of learned helplessness derives from the feelings associated with an awareness of one's powerlessness. Most importantly, the learned helplessness hypothesis holds that mere exposure to uncontrollable events is not sufficient to produce the helplessness deficits. Rather, subjects must come to expect that future outcomes are also uncontrollable in order to exhibit helplessness.

Furthermore, subsequent research revealed that the perception of powerlessness generated in one study tends to be carried into other situations that have nothing at all to do with the previous conditions. Thus, subjects exposed to uncontrollable aversive events develop a mindset that prevents them from perceiving control even when they are in stressful situations where control of outcomes is possible. In this way does exposure to uncontrollability lead to a way of thinking, feeling, and acting under stress that, ironically, fuels stress and maintains a sense of impotence. Thus, it would be no exaggeration to affirm that through this research, experimental psychopathologists have developed a simple, laboratory-based model of injustice that reveals its essential nature, articulates one of its proximal causes, and describes several of its psychological and social effects.

My experiences lead me to believe that the practice of constructive 
resilience may help to protect those who suffer injustice from succumbing to some of these pernicious outcomes. My great-grandmother's generation was practicing it when they sang, "A charge to keep I have..." while doing the best that they could with the meager resources at their disposal. My teacher Ms. Maria Paul was practicing it as she prepared two African American children to learn what they might need to know in order to survive at boarding schools that had been populated, sometimes for hundreds of years, solely by Whites; and my neighbors drew on it to survive when there was simply not enough food available at home. Hatcher taught me about constructive resilience when he explained what is required if we wish to love others and reminded me that every great accomplishment requires effort and self-sacrifice; and my wife, Kathy, demonstrated it when she encouraged me to respond to the prejudice of her grandfather with a quality of noble patience, as through the transformative influence of qualities of character, there was the possibility that he would change.

But resilience does not only consist of the capacity to endure and survive stress; it is reflected in the powers and capacities that unfold as a result of exposure to it. In point of fact, evolutionary theory, developmental psychology, and the world's wisdom traditions converge on the view that even serious encounters with stress appear to be critical to the development of living things. Consider an example from the plant kingdom.

Some years ago, scientists developed a self-contained ecosystem that they named Biosphere II. All was well in Biosphere II except for one problem that puzzled the scientists for quite a while: the trees in Biosphere II, though growing tall, could not stand upright. After much reflection, one of the researchers was struck by the realization that in this totally enclosed ecosystem, there was no wind. $\mathrm{He}$ reasoned that saplings must acquire the strength to stand by resisting the wind; thus the lack of exposure to wind during their early development, he suspected, rendered these saplings incapable of supporting their own weight as adult trees. Stress and hardship are thus paradoxical—like strong winds, they may threaten a living system's health, survival, or wellbeing, and yet, at the same time, they may be critical to calling unrealized capabilities into existence.

We recall that when the trial of Socrates drew to a close and the sentence of death was pronounced against him, he did not lament. Rather, he suggested that a cock be sacrificed in gratitude to Asclepius - the Egyptian god of healing. Why did Socrates act in this way? One interpretation is that through this act, Socrates was seeking to declare that he had been enriched by his encounter with injustice, and that he had gathered an appropriate harvest from his life of earnest struggle. He thus demonstrates constructive resilience and reveals, through 
this act, that he had come to appreciate a profound truth that would be declared by Bahá'u'lláh more than twenty-five centuries later: "Nothing save that which profiteth them can befall my loved ones. To this testifieth the Pen of God, the Most Powerful, the All-Glorious, the Best Beloved" (qtd. in Shoghi Effendi, Advent 82).

It may be that constructive resilience nurtures hope by encouraging us to view social change as an historical process that must, necessarily, extend across the reaches of time. And while we are empowered to contribute our share, however modestly, to "an ever-advancing civilization" (Bahá'u'lláh, Gleanings CIX), we are somewhat protected from many sources of frustration, anxiety, doubt, and depression if we view the events of our lives as fleeting moments, pregnant with possibilities, within a vast historical process that will be carried forward by many others when we are gone. I close with this poignant assertion, made by 'Abdu'l-Bahá, who patiently served the world, as an exile and prisoner, for more than forty years:

The darkness of this gloomy night shall pass away. Again the Sun of Reality will dawn from the horizon of the hearts. Have patiencewait, but do not sit idle; work while you are waiting; smile while you are wearied with monotony; be firm while everything around you is being shaken; be joyous while the ugly face of despair grins at you; speak aloud while the malevolent forces of the nether world try to crush your mind; be valiant and courageous while men all around you are cringing with fear and cowardice. Do not yield to the overwhelming power of tyranny and despotism. Serve the cause of democracy and freedom. Continue your journey to the end. The bright day is coming. The nucleus of the new race is forming. The harbinger of the new ideals of international justice is appearing. The trees of hope will become verdant; the copper of scorn and derision will be transmuted into the gold of honor and praise; the arid desert of ignorance will be transformed into the luxuriant garden of knowledge, the threatening clouds shall be dispelled and the stars of faith and charity will again twinkle in the clear heaven of human consciousness. (141). 


\section{Works CiTED}

'Abdu'l-Bahá. "Extract from Letter to Mr. Alfred E. Lunt." Star of the West, vol. 9, no. 13, 4 Nov. 1918, p. 141.

Bahá'u'lláh. Gleanings from the Writings of Baháu'lláh. Translated by Shoghi Effendi. Bahá'i Reference Library, bahai.org/library/authoritative-texts/ bahaullah/gleanings-writings-bahaullah.

The Bible. King James Version. www.kingjamesbibleonline.org.

Cross Jr., William E. "The Negro to Black Conversion Experience: Towards a Psychology of Black Liberation.” Black World, vol. 20, no. 9, 1971, pp. 13-27.

Hatcher, W. Love, Power and Justice: The Dynamics of Authentic Morality. Bahá'í Publishing Trust, 2004.

Hiroto, D. "Locus of Control and Learned Helplessness." Journal of Experimental Psychology, vol. 102, no. 2, 1974, pp. 187-193.

Shoghi Effendi. The Advent of Divine Justice. 25 Dec. 1938. Bahá'i Reference Library, bahai.org/library/authoritative-texts/shoghi-effendi/advent-divine-justice/.

Universal House of Justice. Letter dated 9 September 2007 addressed "To the Bahá'í students deprived of access to higher education in Iran." Bahá' $i$ Reference Library, bahai.org/library/authoritative-texts/the-universalhouse-of-justice/messages/20070909_001/1\#018930558. 